\title{
DESIGN OF DRAINAGE NETWORK FOR THE FORT AREA, BELAGAVI CITY USING SWMM
}

\author{
Ashwini H.U. ${ }^{1}$, Anand V.Shivapur ${ }^{2}$ \\ ${ }^{1}$ Student, Department of Water and Land Management, Visvesvaraya Technological University, Karnataka, India \\ ${ }^{2}$ Professor, Department of Water and Land Management, Visvesvaraya Technological University, Karnataka, India
}

\begin{abstract}
Due to Urbanization, impermeable area expands leading to frequent flooding. Surface overflow generally relies on rainfall, infiltration, slope, percent of imperviousness and land use. The aim of study carried out by the author is to assess the runoff and design drainage network by storm water management model (SWMM). The Soil Service Conservation Service Curve Number (SCS-CN) is being used in the present approach to determine flood magnitudes generated in each zone of the study area.
\end{abstract}

Keywords: SWMM, High Spatial Resolution, DEM. Rational Method, Land Use/Land Cover. $* * *$

\section{INTRODUCTION}

The extension of impermeable land-cover due to urbanization implies greater storm water overflow volumes and peak flows [5] and also subsequently diminishes different components of the hydrological cycle. Storm water is a generated overflow from the land surface due to rainfall. The significance of urban storm water modeling enhances due to three universal patterns: Urbanization, Population growth and climate change. The initial two patterns generate a fast development of vicinity, creating storm water administration much more complicated.

Storm water administration controls the runoff originated from impermeable zones. Storm water administration is essential in order to avoid physical injuries to individuals and property from flooding [4] as well as to manage the environmental condition, quality and quantity of our water sources and also helps in groundwater recharge and flood protection. Among the hydrologic models U.S. EPA Storm Water Management Model (SWMM) version 5 was adopted which was established in 2014.

\section{STUDY AREA}

Figure 1, shows the study area. The proposed project comes under Bellary Nala catchment, Belagavi district. The extent of study is about 135.43 acres. The latitude and longitude of the project are $15^{\circ} 51^{\prime} 29^{\prime \prime} \mathrm{N}$ and $74^{\circ} 31^{\prime} 27^{\prime \prime}$ 'E respectively. The soil in the locality is clayey soil. The climate of the district is free from extremes, the dry season is from March to June, the monsoon season is from July to October and the winter period from November to February. December to March is the very low rainfall months. August is the wettest month with monthly rainfall in excess of $250 \mathrm{~mm}$. A total of approximately 48 days experience rainy days annually. The temperatures start rising from January to a peak $39^{\circ} \mathrm{C}$ in April, the hottest month in the district. Thereafter it declines during the monsoon period and December is coldest month and the temperatures dips down to $9^{\circ} \mathrm{C}$.

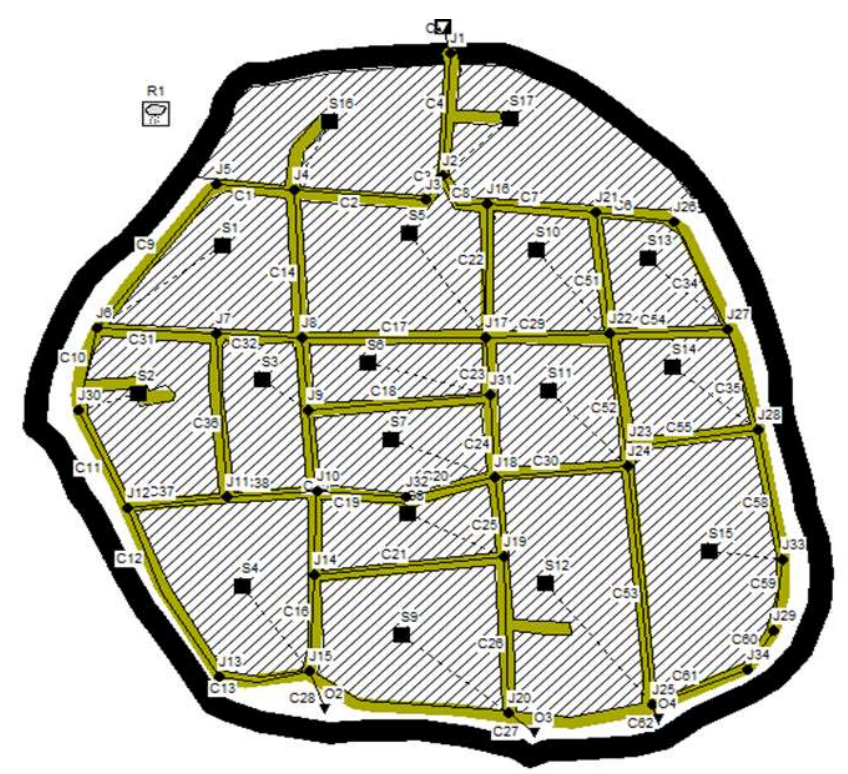

Fig -1: Study area

\section{METHODOLOGY}

On geo-referencing using Google earth image, shape files are created for buildings and roads etc. Of the three method available in SWMM, in the present study SCS Curve Number method is used because of the availability of the desired data [7]. Figure 2, shows the flow chart of the SWMM followed in the present study. SWMM requires different parameters like area, $\%$ of imperviousness, $\%$ of perviousness, Slope, Max. And Min. elevations [6]. These input parameters are derived in Arc-GIS. Zone16 has largest area about $39874 \mathrm{~m} 2$ and Zone 13 has smallest area about $12250 \mathrm{~m} 2$. The highest impervious area is $62.3 \%$ from zone 7 and $100 \%$ pervious area is located in zone 14 . The highest slope in the area is $9.33 \%$ which is from zone 2 , zone 4 , zone 8 , zone 9 and zone 12 . The maximum and minimum elevations in the area is $763 \mathrm{~m}$ and $746 \mathrm{~m}$ respectively. To 
design the drainage discharge, rational method is used and the equation governing the same is given in the following section [2].

$$
Q=C I A
$$

Where:

$\mathrm{Q}=$ discharge in $\mathrm{m}^{3} / \mathrm{s}$

$\mathrm{I}=$ intensity of rainfall in inches/hour

$\mathrm{A}=$ area in acres

$\mathrm{C}=$ Runoff coefficient

For the discharge obtained by the above equation, drainage dimensions are determined using Manning's equation as shown below [7].

$Q=\frac{1.49}{n} A R^{2 / 3} S^{1 / 2}$

Where:

$\mathrm{Q}=$ total discharge $\left(\mathrm{m}^{3} / \mathrm{s}\right)$

$\mathrm{V}=$ velocity of flow $(\mathrm{m} / \mathrm{sec})$

$\mathrm{n}=$ Manning's coefficient of roughness for concrete lined $0.013[1]$

$\mathrm{A}=$ cross-sectional area of the flow $\left(\mathrm{m}^{2}\right)$

$\mathrm{R}=$ hydraulic radius of the channel (m) (flow area/wetted perimeter)
$\mathrm{P}=$ wetted perimeter $(\mathrm{m})$

The dimensions of the drainage obtained so are $0.5 \mathrm{~m}$ width and $1 \mathrm{~m}$ depth.

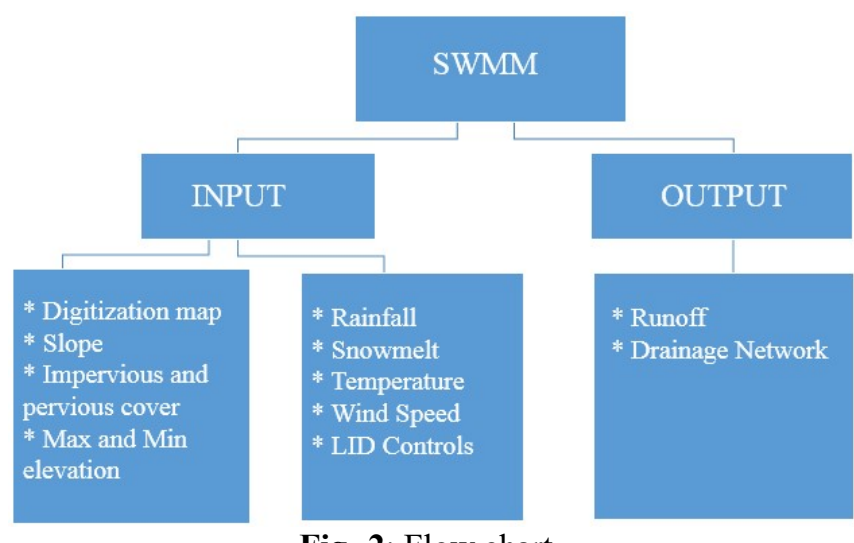

Fig -2: Flow chart

\section{RESULTS AND DISCUSSION}

Because of urbanization the impermeable region has modified and generation of overland flow has increased significantly. Knowing the rainfall-runoff characteristics is quite important for the design of drainage system. To design the drainage network the highest rainfall in the area is considered. The peak runoff varies with the duration of rainfall, in the present work data of $1 \mathrm{hr}$ to $24 \mathrm{hr}$ has been considered and the peak runoff is determined without LID controls and with LID controls [7]. The $24 \mathrm{hr}$ rainfall event for zones 1 to 6 without LID is shown in Figure 3 below. The highest runoff without LID is found to be from zone 16 which is about $1.31 \mathrm{~m}^{3} / \mathrm{s}$ and the lowest runoff is from zone 13 which is about $0.40 \mathrm{~m}^{3} / \mathrm{s}$ (Ref. Figure 4 ).

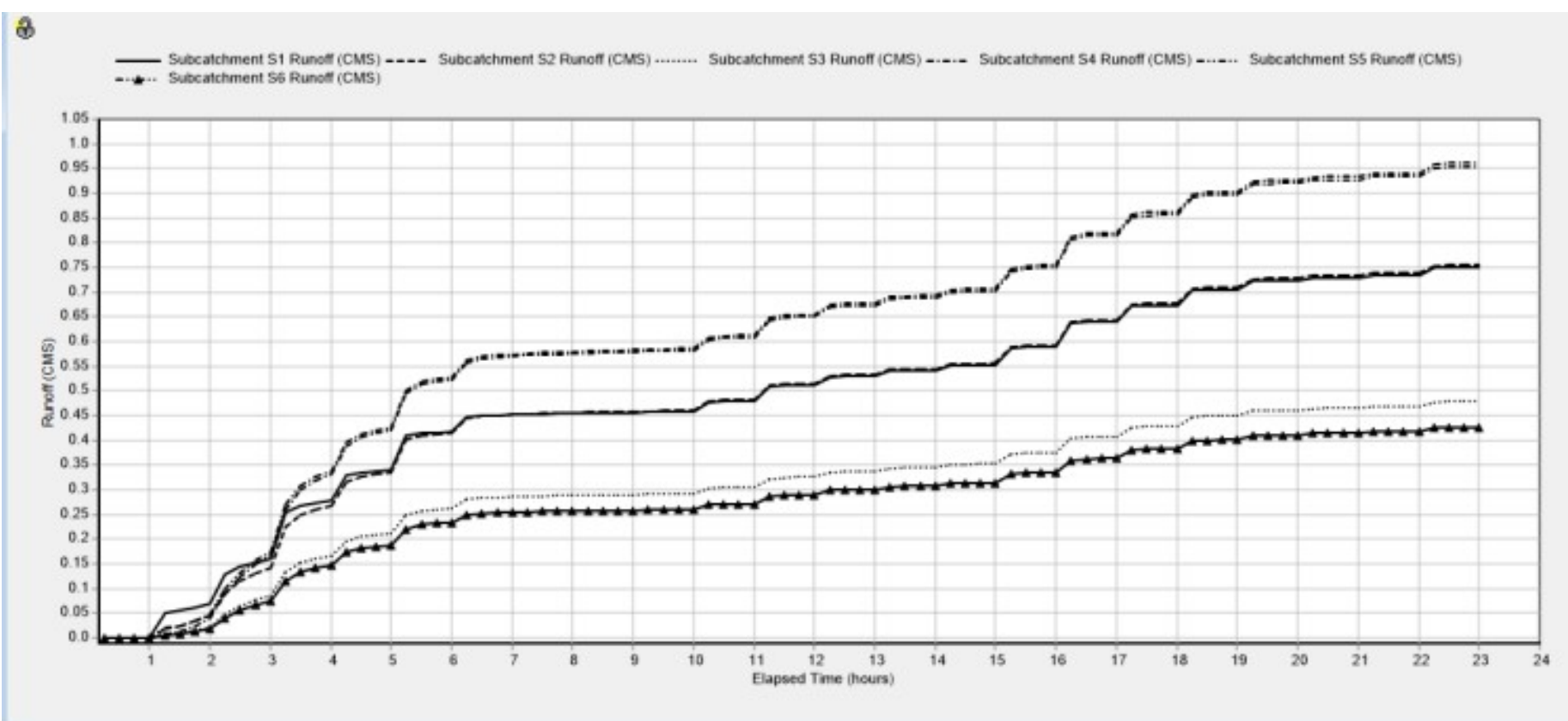

Fig -3: $24 \mathrm{hr}$ rainfall event for sub-catchment 1 to 6 without LID 
3

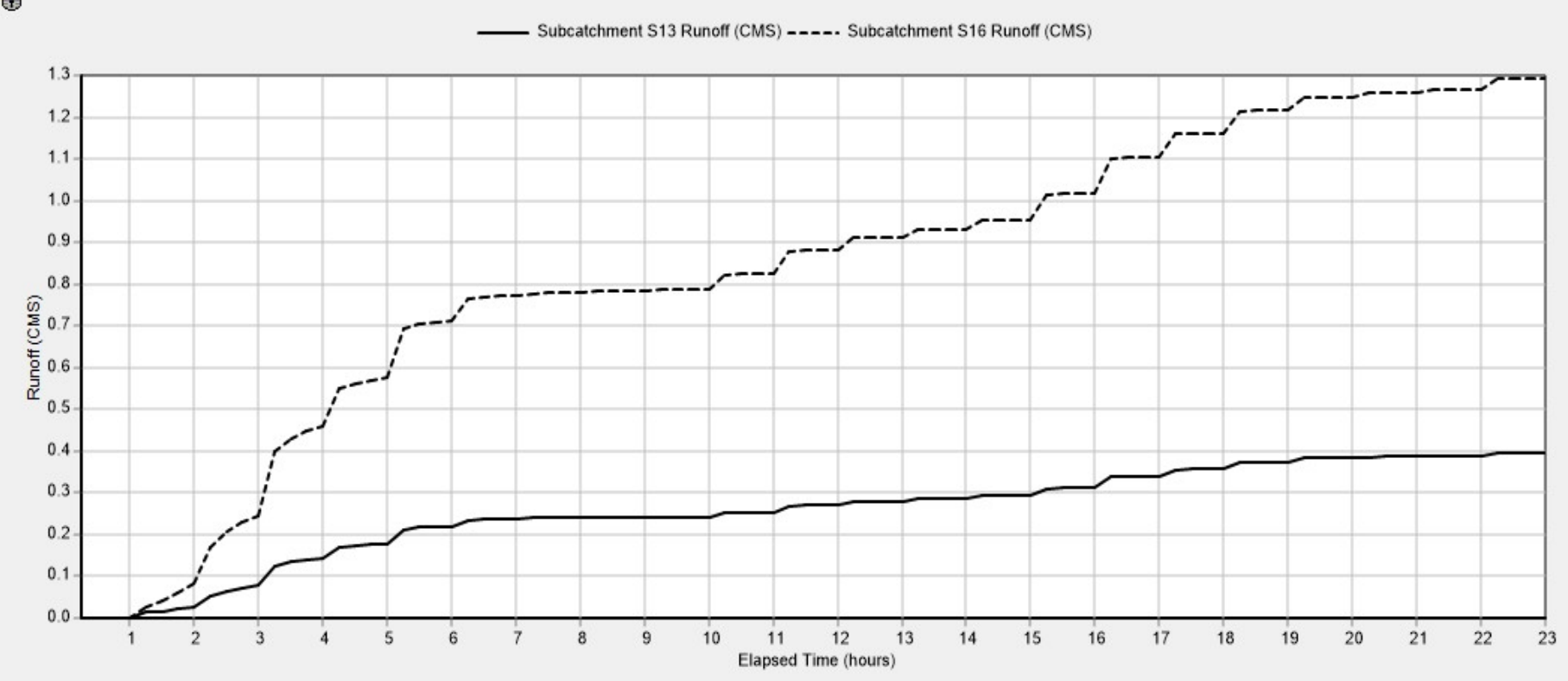

Fig -4: Highest runoff from Zone 16 and lowest runoff from Zone 13 without LID

The highest runoff with LID is found to be from zone 16 which is about $0.91 \mathrm{~m}^{3} / \mathrm{s}$ and the lowest runoff is from zone 13 which is about $0.28 \mathrm{~m}^{3} / \mathrm{s}$ (Ref. Figure 5).

읍

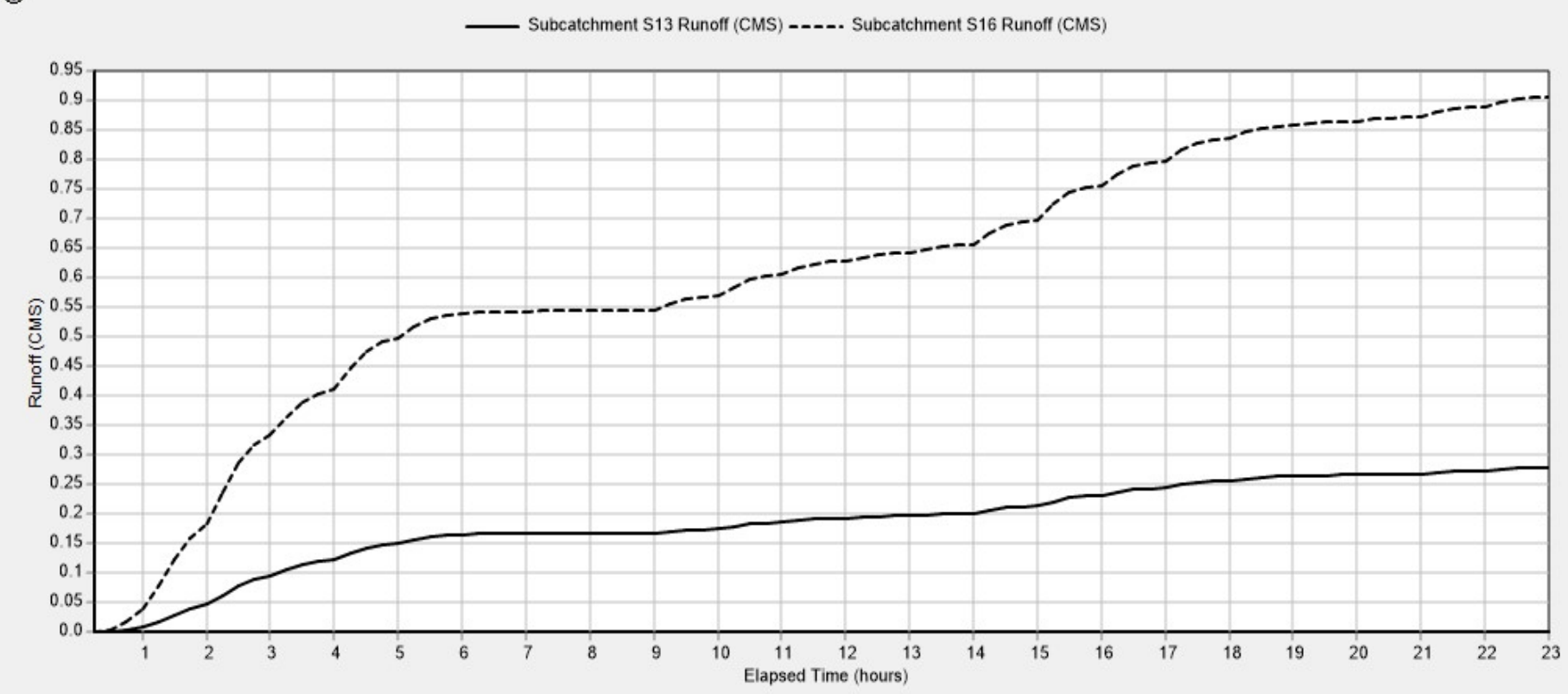

Fig -5: Highest runoff from Zone 16 and lowest runoff from Zone 13 with LID

To know the depth of storm water in the designed drainage network the water surface profiles were plotted [3]. This will helps us to know whether the designed dimension is sufficient to carry the generated flow in it. The water surface profile from junction 16 to Outfall 3 and junction 5 to outfall
2 are shown in Figure 6. These profiles shows that the designed dimensions are sufficient to carry the runoff generated from the concerned zone. 

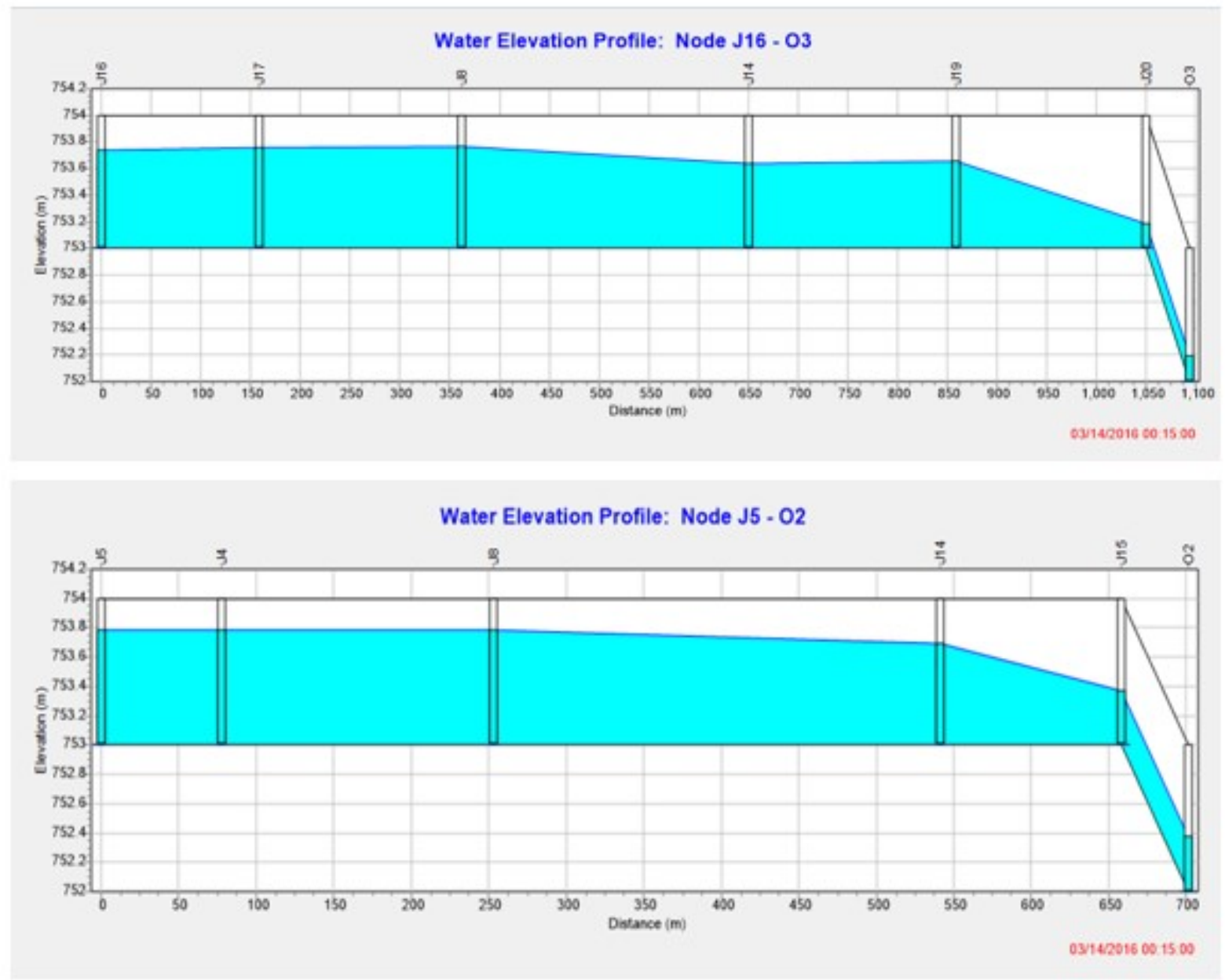

Fig -6: Water elevation profile for Nodes

The results obtained through the rational methods were compared with the results obtained through the SWMM by plotting them on graph paper and a regression coefficient of 0.99 has been obtained signifying the validity of SWMM for determination of storm water magnitudes.

\section{CONCLUSION}

The results obtained using the rational method and the SWMM software are comparable. Hence the use of SWMM for storm water drainage is justified and is quicker. The study area covering 17 sub catchments is almost level and hence the depths of storm water drainage is kept at all the junctions. The size of the storm water drainage required is found to be $1.00 \mathrm{~m}$ by $0.5 \mathrm{~m}$. While providing the size of storm water drainage, the nature of terrain is considered and it is suggested to adopt the same size throughout the network. The water surface profile plotted to various stretches justifies the adoption of dimensions of storm water drainage.

The zones generate more runoff when it is not designed with Low Impact Development (LID) and the runoff generated is less when it is designed with LID. The highest runoff generated is from the zone 16 without LID is $1.31 \mathrm{~m}^{3} / \mathrm{s}$ and with LID is $0.91 \mathrm{~m}^{3} / \mathrm{s}$. While the zone 13 generates the lowest runoff of the magnitude $0.40 \mathrm{~m}^{3} / \mathrm{s}$ and $0.28 \mathrm{~m}^{3} / \mathrm{s}$ without and with LID respectively. Hence it is found that runoff decreases by considering LID in the design.

\section{REFERENCES}

[1] Alfred J. Kalyanapu., Steven J. Burian., and Timothy N. McPherson. (2009). "Effect of land use-based surface roughness on hydrologic model output." Journal of Spatial Hydrology. Volume 9, No.2, pp: 51-71.

[2] C. H. Tan., S. F. Shih., A. M. Melesse., J.D. Jordan., and S. S. Yeh. (2001). "RS and GIS in Runoff coefficient estimation for irrigated regions." International Commission on Irrigation and Drainage, 1st Asian Regional Conference, Seoul.

[3] Gizegorz Scieranka. (2013). "Modeling storage channel using SWMM5 Software." Architecture Civil Engineering Environment. No 1, pp: 87-94.

[4] [Hussein A. Obaid., Shamsuddin Shahid., K.N. Basim., and Chelliapan Shreeshivadasan. (2014). "Modeling Sewerage Overflow Residential Area Using SWMM." Malaysian Journal of Civil Engineering. Volume 26, Issue 2, pp: 163-171.

[5] Janet Barco., Kenneth, M. Wong., Michel, K. Stenstrom and F. Asce. (2008). "Automatic Calibration of the U.S.Epa SWMM Model for a large urban catchment.” J. Hydraul. Eng. 134, pp: 466-474. 
[6] Robert S. Arthur. (2010). "Storm water Runoff Simulation Using SWMM: Evaluating Storm water Management on the University of Virginia Grounds." A Research Paper in CE 4995. pp: 1-21.

[7] Rossman., Lewis A. (2014). "Storm Water Management Model User's Manual." U.S. Environmental Protection Agency, Cincinnati, OH. EPA/600/R-05/040.

\section{BIOGRAPHIES}

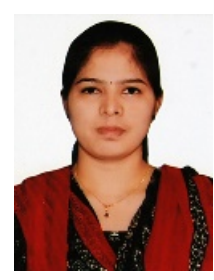

Ashwini H.U. M Tech Scholar, Department of Water and Land Management, Center for P.G. studies, VTU, Belagavi. Email - huashwini@gmail.com

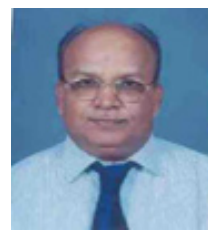

Dr. Anand V. Shivapur: He is currently working as Professor and HOD of Water and Land Management dept., Centre for PG Studies, VTU, Belagavi. He has total experience of 31 years in teaching, administration and research. He has published more than 25 research papers in National as well as International journals, 60 papers in Conf., Seminar etc. He has guided $2 \mathrm{PhD}$ students and 6 scholars are pursuing research. His research areas are Water Mgmt., Hydrology, Use of RS and GIS for irrigation and watershed.

Email-av_shivapur@rediffmail.com 